\title{
Normative Legal Base of Municipal, Regional, Federal and International Levels on Support and Development of Arts and Crafts of Indigenous Small-Numbered Peoples
}

\author{
Vladimir S. Luzan and Natalia P. Koptseva* \\ Siberian Federal University \\ 79 Svobodny, Krasnoyarsk, 660041, Russia
}

Received 01.06.2017, received in revised form 27.09.2017, accepted 06.10.2017

\begin{abstract}
The stable development of the indigenous small-numbered peoples of the North, Siberia and the Far East of the Russian Federation in the context of global transformations depends not only on mobilizing the internal resources of the peoples themselves, but also on the actual mechanisms for preserving traditional forms of management and crafts. Especially it becomes relevant for arts and crafts as one of the main forms of preserving the national identity of these peoples, which, at the same time, is the least attractive from an economic point of view, unlike, for example, traditional forms of management (fishing, reindeer breeding, hunting etc.). In this regard, the article attempts to consider the current normative legal base of the municipal, regional, federal and international levels to support and develop arts and crafts of indigenous small-numbered peoples of the North, Siberia and the Far East in the Russian Federation.

In conclusion, the author outlines the general conclusions and the likely trends in the development of the normative legal framework for the support and development of arts and crafts of indigenous smallnumbered peoples in contemporary socio-economic conditions.
\end{abstract}

Keywords: indigenous small-numbered peoples, arts and crafts, cultural policy, the state, primordial habitat, interaction.

The reported study was funded by the Krasnoyarsk Region Science and Technology Support Fund according to the research project Decorative and Applied Art of the Indigenous Peoples of the Krasnoyarsk Territory: Current Status, Prospects for Development.

The reported study was funded by the Russian Foundation for Basic Research, Government of Krasnoyarsk Territory, Krasnoyarsk Region, Science and Technology Support Fund for the research project № 17-16-24601.

DOI: 10.17516/1997-1370-0152.

Research area: culturology.

(C) Siberian Federal University. All rights reserved

* Corresponding author E-mail address: vladimir_luzan@list.ru 
Introduction to the research problem. The stable development of indigenous smallnumbered peoples of the North, Siberia and the Far East of the Russian Federation in the context of global transformations depends not only on mobilizing the internal resources of the peoples themselves, but also on the actual mechanisms for preserving traditional forms of management and crafts. Especially it becomes relevant for arts and crafts as one of the main forms of preserving the national identity of these peoples, which, at the same time, is the least attractive from the economic point of view, unlike, for example, such traditional forms of management as fishing, reindeer herding, hunting, etc.

Undoubtedly, the state plays a key role in the process of preserving the decorative and applied arts of the indigenous people, both at the federal and regional levels, as well as local self-government bodies within its own powers. In this regard, it is necessary to analyze the current regulatory framework. This is especially important in the context of global climate change and active industrial development of the primordial habitat of indigenous peoples, which introduces significant adjustments to traditional methods of management. In addition, the rawmaterial orientation of the Russian economy suggests that in the short and long-term prospects, the volume of industrial development of the territories of traditional nature management of indigenous small-numbered peoples will only grow, therefore, the problem of preserving and developing the culture of these peoples as a whole, and arts and crafts as an integral part of it acquires a strategic importance for the state cultural policy.

Methodology of the research. The main theoretical and methodological basis of the research was the work of Russian scientists, revealing the current state of legal mechanisms for the support and development of the arts and crafts of the indigenous small-numbered peoples of the North, Siberia and the Far East of the Russian Federation.

The author used materials describing the state of the arts and crafts of indigenous small peoples at the current stage as a theoretical basis of this study, as well as the existing regulatory legal documents in this area of the federal, regional and municipal levels.

The study of theoretical materials related to the preservation and development of the arts and crafts of indigenous small peoples living on the territory of the Russian Federation led to the use of an analytical-descriptive method that includes both the analysis of individual elements and documents and the compilation of data obtained during the study.

Conceptual bases of the research. In the domestic scientific and scientific-journalistic literature, the studies of various aspects related to the preservation and development of the arts and crafts of indigenous small-numbered peoples of the Russian Federation were reflected in the work of politicians, scientists, government and public figures. At the same time, existing works can be divided into three main groups:

Studies that analyze the conceptual foundations of the existing mechanisms of state support for indigenous small-numbered indigenous peoples as a whole (S.A. Arutiunov, R.G. Abdulatipov, V.Iu. Zorin, M.N. Guboglo, L.M. Drobizheva, V.A. Mikhailov, K.V. Kalinina, V.A. Tishkov and others);

Studies of practical focus, devoted to the study of existing problems in building the mechanisms of interaction between the state and local self-government bodies with indigenous small-numbered peoples, including with respect to the preservation and development of arts and crafts (A.Kh. Abashidze, V.A. Kriazhkov, 
L.V. Andrichenko, F.S. Donskoi, K.D. Arakcha, T.Ia. Khabrieva, P.Kh. Zaidfudim, B.S. Krylov, A.I. Pik, Iu.A. Samar, S.N. Khariuchi and others); Art and cultural studies based on the analysis of specific works of arts and crafts or periods of its development, as well as their role in preserving the cultural self-identification of indigenous small-numbered peoples and influence on socio-cultural processes in general (L.L. Bokotei， E.V. Vorozhtsova， V.K. Ivanov, N.P. Koptseva, N.M. Libakova, N.N. Pimenova, V.V. Podmaskin, A.I. Rudenko and others).

Statement of the problem. In modern Russian realities, it becomes obvious that the existing legal mechanisms for preserving the traditional culture of indigenous peoples are far from always effective and applicable in practice due to the decentralization of the public administration system and a significant resource shortfall in local government bodies.

Consequently, the problem of improving the regulatory legal framework for the preservation and development of the arts and crafts of indigenous small-numbered peoples of the Russian Federation, of course, belongs to the sphere of state cultural policy. In this regard, it should be noted that for the first time in the modern history of Russia, the Decree of the President of the Russian Federation No. 808 of December 24, 2014 approved a fundamental document that defines the conceptual provisions for the development of cultural policy in the short and long term and the state's tasks in this area, in other words, the Fundamentals of the state cultural policy of the Russian Federation. However, the process of developing a strategic document on the implementation of the Fundamentals of Cultural Policy lasted until the beginning of 2016 and was accompanied by serious disputes not only within the expert community, but also between various executive authorities, primarily the Ministry of Culture and the Ministry of Finance of the Russian Federation. Nevertheless, as a result of the work, the order of the Government of the Russian Federation No. 326-p dated 29.02.2016 approved the Strategy of State Cultural Policy for the period until 2030.

In accordance with the Fundamentals of State Cultural Policy, the state sets a task for preserving ethnic cultural traditions and supporting the folk art based on them, preserving ethno-cultural diversity as one of the significant sources of professional culture and an important component of ethnonational identity. ${ }^{1}$ The fulfillment of this task can be significantly hampered without taking appropriate measures to preserve and develop the arts and crafts of indigenous small-numbered peoples as one of the most accessible forms of constructing the selfidentification of these peoples. In this regard, it is necessary to analyze the current regulatory framework in this area at all levels.

Discussion. The analysis of the world experience and Russian practice demonstrates that the normative legal regulation becomes extremely important, especially in the transitional moments that have been occurring in Russian society, taking into account the growing globalization processes, since the 1990s. This situation is largely due to the fact that in the conditions of building a federative state and civil society in Russia, the current and adopted normative legal acts determine all aspects of the functioning of not only the state itself, but all other spheres of public and even private life, including preservation and development of arts and crafts of indigenous peoples.

In this regard, the Russian Federation has become one of the initiators of the proclamation of the Second International Decade of the World's Indigenous Peoples in 2005/2014 in the United Nations, although it did not support the UN 
Declaration on the Rights of Indigenous Peoples at the 61st session of the UN General Assembly (September 13, 2007).

The basic law that is the Constitution of the Russian Federation (hereinafter - the Constitution) is the basis of the legal regulation of the preservation and development of the arts and crafts of low-numbered peoples at all levels. For example, Art. 44 of the Constitution guarantees the citizen freedom of literary, artistic, scientific, technical and other forms of creativity, teaching. Intellectual property is protected by law. Everyone has the right to participate in cultural life and to use cultural institutions and cultural values. $^{2}$

In addition, the Constitution enshrines provisions in accordance with which cultural activity in the Russian Federation is an inalienable right of every citizen regardless of national and social origin, language, sex, political, religious and other convictions, residence, property, education, profession or other circumstances. The implementation of the above provisions requires the existence of a developed normative legal framework in the state in the field of culture and copyright, which has mainly already been formed.

Thus, the Constitution establishes not only the basic rights of citizens in the sphere of cultural policy in general, but also fixes the state's obligations to ensure the corresponding rights. In this regard, the current normative legal regulation in the sphere of preservation of the arts and crafts of indigenous minorities is represented by several legislative acts at the federal level. The following branch laws can be identified as key ones:

1) Federal Law No. 3612-I of October 9, 1992 "Fundamentals of the Russian Federation Legislation on Culture";

2) Federal Law No. 82-FZ of April 30, 1999 "On Guarantees of the Rights of Indigenous Peoples of the Russian Federation";
3) Federal Law of January 6, 1999 No. 7-FZ "On Folk Artistic Crafts";

4) Federal Law of May 7, 2001 No. 49-FZ “On the Territories of Traditional Nature Management of Indigenous Peoples of the North, Siberia and the Far East of the Russian Federation";

5) Federal Law No. 104-FZ of July 20, 2000 "On General Principles for the Organization of Communities of Indigenous Peoples of the North, Siberia and the Far East of the Russian Federation";

6) Federal Law No. 131-FZ of October 6, 2003 “On General Principles of Organization of Local Self-Government in the Russian Federation".

The above list of legislative acts regulating the legal relations of stakeholders in the sphere of arts and crafts of indigenous peoples is not exhaustive, since it does not include various by-laws, as well as non-sectoral legislation and regional legislation of the subjects of the Russian Federation in the sphere of cultural policy. In addition, as a result of the administrative reform in the Russian Federation, local self-government bodies also obtained the right to adopt relevant regulatory legal acts on issues of local significance at the local level in the field of culture specified in Federal Law No. 131-FZ of 06.10.2003 “On General Principles of Organization of Local Government in the Russian Federation".

It should be noted that in the context of the research conducted, the concepts of "arts and crafts" and "folk artistic craft" should be considered synonymous and understood as "one of the forms of folk art, the creation of artistic products of utilitarian and (or) decorative design, based on collective development and successive development of traditions of folk art in a certain area in the process of creative manual and (or) mechanized work of masters of folk arts"3.

The situation arises due to the fact that normative legal documents often use the notion 
of "folk artistic craft" when in theoretical and practical scientific research they use the term "arts and crafts". At the same time, it should be noted that, in accordance with the current legislation, state support measures concern only those art crafts that are classified in accordance with the established procedure. "The attribution of products to the products of folk artistic crafts is carried out on the basis of the decisions of artistic and expert councils on folk artistic crafts, adopted on the basis of the examination of the samples and unique items of folk artistic crafts. These decisions are made in accordance with the list of types of productions and groups of products of folk artistic crafts, which is approved in the manner established by the Ministry of Culture of the Russian Federation". 4

In addition, in accordance with Art. 22. of the Fundamentals of the Legislation of the Russian Federation on Culture "The Russian Federation guarantees its protection (patronage) with regard to the preservation and restoration of the cultural and national identity of the smallnumbered ethnic communities of the Russian Federation through exceptional protection and incentives provided for by federal state programs of socioeconomic, environmental, national and cultural development". ${ }^{5}$

In section VII of the Fundamentals of the Legislation of the Russian Federation on Culture, competence in the sphere of cultural policy is divided between the federal executive bodies of the Russian Federation, primarily the Ministry of Culture of the Russian Federation, and the relevant bodies of the subjects of the Federation and local authorities in the field of culture (Articles 37, 39 and 40). At the same time, the Fundamentals of the RF legislation on culture, in the opinion of both active specialists in the social and cultural sphere, and scientists require substantial refinement. In this regard, over the past ten years, the Ministry of Culture of the Russian Federation has repeatedly attempted to develop new versions of the main federal law in the field of cultural policy, which to this day have not been crowned with success.

To date, specific powers in the sphere of cultural policy for each level of government are defined as follows ${ }^{6}$ :

1. Powers of the Russian Federation are:

- to ensure human rights and freedoms in the field of culture;

- to establish the foundations of federal cultural policy, adopt federal legislation in the sphere of cultural policy and federal state programs for the preservation and development of culture;

- to carry out legal regulation of property relations, the basis of economic activity and the order of disposal of the national cultural heritage of the Russian Federation;

- to form the federal budget in terms of spending on culture;

- to coordinate foreign policy in the field of cultural cooperation;

- to regulate the export and import of cultural property;

- to determine the principles of the state policy in the field of training, employment, remuneration of labor, establishing the minimum amount of royalties in federal cultural institutions;

- to use, preserve, popularize objects of cultural heritage that are in federal ownership;

- to protect and preserve especially valuable objects of cultural heritage of the peoples of the Russian Federation.

2. Powers of public authorities of the subjects of the Federation are:

- to form and maintain archival funds of the subjects of the Federation;

- to use, preserve, popularize objects of cultural heritage that are in the ownership of the subject of the Federation; 
- to provide library services for the population in the libraries of the constituent entity of the Federation, manning and ensuring the safety of their library collections;

- to create and maintain state regional museums;

- to organize and support institutions of culture and art;

- to support folk artistic crafts;

- to support regional and local national and cultural autonomy, support the study of national languages and other subjects of ethnocultural orientation in educational institutions.

3. Powers of local self-government bodies are:

- to provide population with library service and acquisition of library funds;

- to create conditions for organizing leisure and providing residents with services of cultural organizations;

- to create conditions for the development of local traditional folk artistic creativity;

- to participate in the preservation, revival and development of folk artistic crafts;

- to create municipal museums;

- to create conditions for mass recreation of residents of settlements and organize the arrangement of places for mass recreation;

- to provide additional education;

- to protect and preserve objects of cultural heritage of local importance;

- to form and maintain a municipal archive.

Thus, the powers of the subjects of the Federation and local self-government bodies regarding the preservation and development of the arts and crafts of indigenous peoples use too general formulas such as "support of folk artistic crafts" and "participation in the preservation, revival and development of folk artistic crafts" and do not offer specific support measures or, at least, mandatory requirements for the amounts and forms of this support, which allows for too general interpretation of these powers and minimize efforts of government agencies on their practical implementation.

At the same time, in order to minimize the consequences of broad interpretation of powers and fulfillment of one's own powers in the sphere of preservation of arts and crafts of indigenous peoples, most of the subjects of the Russian Federation where the indigenous peoples live have adopted their own regulatory legal acts (laws, resolutions, programs for socio-economic development and etc.) that regulate this area. In total, according to the report "Sustainable development of indigenous small-numbered peoples: the experience of Russia"7, Russia has adopted more than 1200 regional normative legal acts concerning the implementation of the rights of indigenous small-numbered peoples.

For example, the Draft Strategy for the Social and Economic Development of the Krasnoyarsk Territory until $2030^{8}$ emphasizes that with regard to indigenous small-numbered peoples, the implementation of policies aimed at supporting and developing the traditional way of life and traditional economic activities should be continued, since in conditions of active industrial development of the original habitat, it is the preservation of traditional ways of life and economic activities that is the basis for the existence of small-numbered peoples as distinct ethnic communities.

In addition, in 2013 the state program of the Krasnoyarsk Territory "Creation of conditions for raising the standard of living of the indigenous small-numbered peoples of the Krasnoyarsk Territory" approved by the Decree of the Government of the Krasnoyarsk Territory No. 520-p dated November 30, $2013^{9}$ was adopted. In accordance with this program, the total amount of budgetary allocations for the implementation 
of the program is 2107237.5 thousand rubles, including:

- 2020685.4 thousand rubles - regional budget funds, 86552.1 thousand rubles - federal budget funds, including by years:

- 2014 - 366002.4 thousand rubles, of which 353438.6 thousand rubles are regional budget funds, 12563.8 thousand rubles are federal budget funds;

- 2015 - 432,191.7 thousand rubles, of which 404186.8 thousand rubles are regional budget funds, 28004.9 thousand rubles are federal budget funds;

- 2016 - 465674.1 thousand rubles, of which 439145.6 thousand rubles are regional budget funds, 26528.5 thousand rubles are federal budget funds;

- 2017 - 431,412.1 thousand rubles, of which 411,957.2 thousand rubles are regional budget funds, 19454.9 thousand rubles are federal budget funds;

- 2018 - 411,957.2 thousand rubles, of which 411,957.2 thousand rubles are regional budget funds.

At the same time, in accordance with the specified program, the provision of material support, including in the form of social payments, is foreseen primarily for reindeer herders, hunters and fishermen and does not apply to masters of arts and crafts.

On the whole, the analysis of regional legislation shows that the main normative legal acts regulating the preservation and development of arts and crafts of indigenous small-numbered peoples are the following types of regional laws:

- on culture;

- on indigenous small-numbered peoples;

- the basis of legal guarantees for indigenous small-numbered peoples of the North;

- on objects of cultural heritage (monuments of history and culture) of the peoples of the Russian Federation.
In the structure of the executive bodies of some constituent entities of the Russian Federation, structural units for the affairs of indigenous minorities of the North, Siberia and the Far East have been established in order to coordinate relevant regional specialpurpose programs and issues of socio-economic development of these peoples. In particular, the Agency for the Development of Northern Territories and the support of indigenous smallnumbered peoples function in the Krasnoyarsk Territory, the main tasks of which are:

- to ensure the implementation of state policy in the regional development of the northern territories of the Krasnoyarsk Territory;

- to ensure the protection of the original habitat and traditional way of life of indigenous small-numbered peoples of the Russian Federation living on the Krasnoyarsk Territory;

- to guarantee the original development of indigenous small-numbered peoples.

It should be noted that the list of traditional economic activities of the indigenous smallnumbered peoples of the Russian Federation, approved by Order No. 631-r of the Government of the Russian Federation of May 8, 2009, included "artistic crafts and folk crafts (forging and ironwork, making utensils, boats, sledges, other traditional means of transportation, musical instruments, birch bark products, stuffed game animals and birds, souvenirs from deer fur and game animals and birds, other materials, weaving from grasses and other plants, knitting nets, carving on bone, carving on wood, sewing of national clothes and other kinds of crafts related to the processing of fur, leather, bone and other materials)". ${ }^{10}$

Therefore, the state is obliged to provide support to these kinds, however, to date, this has not been fully realized, despite the fact that there are specialized state and municipal cultural institutions (art centers, museums, etc.) engaged 
in conservation and development of arts and crafts of indigenous small-numbered peoples, and various activities to popularize folk artistic crafts are systematically carried out.

Conclusions. Thus, the analysis of the regulatory legal framework for the support and development of the arts and crafts of indigenous small-numbered peoples of the Russian Federation in contemporary socio-economic conditions allows us to conclude that the concepts of "arts and crafts" and "folk artistic craft" are perceived by the legislator as synonyms. The situation arises due to the fact that normative legal documents often use the notion of "folk artistic craft", and in theoretical and practical scientific research, on the contrary, they use the term "arts and crafts". At the same time, it should be noted that, in accordance with the current legislation, state support measures concern only those art crafts that are classified in accordance with the established procedure.

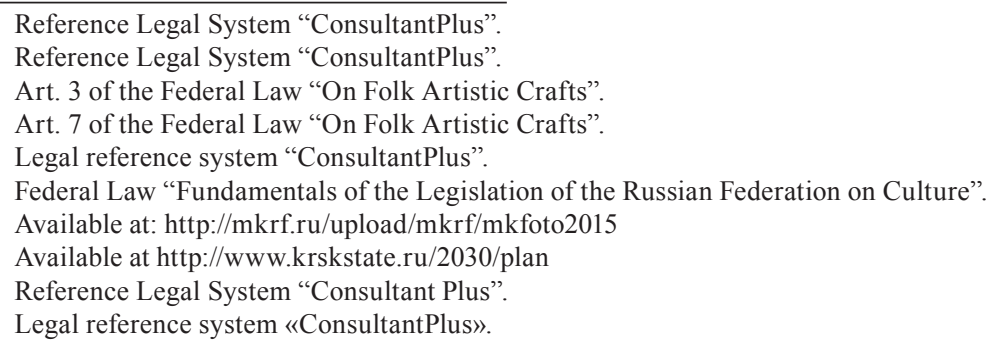

\section{References}

Amosov, A.E., Bakhova, N.A., Bokova, V.I. (2012). Korennye malochislennye narody Severa i Sibiri v usloviiakh global'nykh transformatsii (na materiale Krasnoiarskogo kraia). T.1. Kontseptual'nye i metodologicheskie osnovy issledovaniia. Etnokul'turnaia dinamika korennyk malochislennykh narodov Krasnoiarskogo kraia [Indigenous minorities of the North and Siberia under conditions of global transformations (based on the material of the Krasnoyarsk Territory), 1. Conceptual and methodological bases of research. Ethnocultural dynamics of the indigenous small-numbered peoples of the Krasnoyarsk Territory]. Krasnoyarsk, SFU.

Andrichenko, L.V., Postnikov, A.E. (2008). Problemy razgranicheniia zakonodatel'nykh polnomochii $\mathrm{v}$ sfere zashchity iskonnoi sredy obitaniia i traditsionnogo obraza zhizni KMNS Rossii [The problems of differentiation of legislative powers in the field of protection of the 
original habitat and the traditional way of life of the indigenous small-numbered peoples of the Russian Federation], In Zhurnal rossiiskogo prava [Journal of Russian Law], 5, 28-37.

Araslanov, R. (2010). Problemy traditsionnykh promyslov korennykh narodov Severa [Problems of traditional crafts of indigenous peoples of the North], In Ekonomist [Economist], 7, 68-77.

Bukova M.I. (2017). Northern Studies Expert and Anthropologist Vladimir Germanovich TanBogoraz: «All-Russian Art Newsman», In Siberian Journal of Anthropology, 6 (1), 35-42.

Chapin, F.S., Peterson, G., Berkes, F., Callaghan, T.V., Angelstam, P. (2004). Resilience and Vulnerability of Northern Regions to Social and Environmental Change, In A Journal of the Human Environment, 33 (6), 344-349.

Ford J., McDowell G., Jones J. (2014). The state of climate change adaptation in the Arctic, In Environmental Research Letters, 9 (10).

Jegede, A.O. (2016). The environmental and economic implications of the climate change and extractive industry nexus in Africa, In Environmental Economics, 7 (4-1), 95-103.

Konstitutsiya Rossiyskoy Federatsii [Constitution of the Russian Federation] (1993). Moscow, 39 p.

Koptseva, N.P. (2014). Expert analysis of the main trends of Northern Siberia's indigenous smallnumbered peoples economic development, In Economic Annals-XXI, 11-12, 93-96.

Koptseva, N.P. (2015). The current economic situation in Taymyr (the Siberian Arctic) and the prospects of indigenous peoples' traditional economy, In Economic Annals-XXI, 9-10, 95-97.

Koptseva, N.P., Kirko, V.I. (2014). The information basis for formation of positive ethnic identities in the process of acculturation of indigenous peoples of the Arctic Siberia (Krasnoyarsk, Russia), In Life Sci J, 11 (8), 479-483.

Koptseva, N.P., Kirko, V.I. (2014). Ethic identification of indigenous people of the Siberian Arctic, In American Journal of Applied Sciences, 11 (12), 1969-1975.

Koptseva, N.P., Kirko, V.I. (2014). Modeling of the basic processes and traditional way of life of indigenous peoples of Krasnoyarsk region (Eastern Siberia), In Life Sci J, 11(10), 489-494.

Koptseva, N.P., Kirko, V.I. (2014). Modern specificity of legal regulation of Cultural Development of the Indigenous Peoples of the Arctic Siberia under the global transformations, In Life Sci J, 11 (9), 314-319.

Koptseva, N.P., Kirko, V.I. (2014). Post-Soviet practice of preserving ethnocultural identity of indigenous peoples of the North and Siberia in Krasnoyarsk Region of the Russian Federation, In Life Sci J, 11 (7), 180-185.

Koptseva N.P., Kirko V.I. (2014). Processes of acculturation of Khakases (indigenous people of Southern Siberia), living outside of Khakassia in the urban and student environment, In American Journal of Applied Sciences, 11 (12), 1969-1975.

Koptseva, N.P., Kirko, V.I. (2014). Specificity of ethnogeny indigenous peoples by Central Siberia in the transition from the traditional type of society to modern society, In Life Sci J, 11(7), 409-413.

Koptseva, N.P., Kirko, V.I. (2015). The impact of global transformations on the processes of regional and ethnic identity of indigenous peoples Siberian Arctic, In Mediterranean Journal of Social Sciences, 6 (3), 217-224.

Koptseva, N.P., Reznikova, K.V. (2015). Refinement of the causes of ethnic migration North Selkups based on the historical memory of indigenous ethnic groups Turukhansk district of Krasnoyarsk Krai, In Bylye gody, 4 (38), 1028-1038. 
Korennye malochislennye narody Severa i promyshlennoe razvitie Arktiki: (Etnol. monitoring $v$ Yamalo-Nenetskom avt. okruge) [Indigenous minorities of the North and industrial development of the Arctic (Ethnological monitoring in the Yamalo-Nenets Autonomous Okrug)] (2011). Moscow, Shadrinsk, 267 p.

Kriazhkov, V.A. (2010). Korennye malochislennye narody Severa v rossiiskom prave [Indigenous Peoples of the North in Russian Law]. Moscow, Norma, 560 p.

Kul'tura korennykh i malochislennykh narodov Severa $v$ usloviiakh global'nykh transformatsii [Culture of indigenous and small-numbered peoples of the North in conditions of global transformations]. (2011). Saint-Petersburg, Eidos, 174 p.

Lazhentsev, V.N. (2002). Severnye regiony v sisteme vnutrennikh i vneshnikh otnoshenii Rossii [Northern regions in the system of internal and external relations of Russia], In Ekonomicheskaia nauka sovremennoi Rossii [Economic science of modern Russia], 4, 72-81.

Libakova, N.M., Kolesnik, M.A., Sergeeva, N.A., Sertakova, E.A. (2017). Research Opportunities in Art Anthropology based on the Example of the Bone Carving Works of Siberian Masters, In Siberian Journal of Anthropology, 6 (1), 22-34.

Libakova, N.M., Sitnikova, A.A., Sertakova, E.A., Kolesnik, M.A., Ilbeikina, M.I. (2014). Interaction of the Yakut ethnicity and biological systems in the territory of the Sakha Republic (Hordogoy settlement, Suntarsky District) and Krasnoyarsk Krai (Essey settlement, Evenks District), In Life Sci J, 11 (6s), 585-592.

Litviakova, A.B. (2007). Korennye malochislennye narody Eniseiskogo Severa: ekonomicheskie, sotsiokul'turnye, pravovye problemy zhiznedeiatel'nosti i integratsii [Indigenous peoples of the Yenisei North: economic, socio-cultural, legal problems of life and integration]. Krasnoyarsk, Filial $\mathrm{SPb}$ IVESEP, $185 \mathrm{p}$.

Maharjan, S.K. (2012). Climate risks, vulnerabilities and climate change adaptation practices in selected indigenous communities in Asia. Sixth international conference on community-based adaptation the melia hotel, Hanoi, Vietnam.

Mangataeva, D.D. (2000). Evoliutsiia traditsionnykh sistem zhizneobespecheniia korennykh narodov Baikal'skogo regiona [Evolution of traditional life support systems for indigenous peoples of the Baikal region]. Novosibirsk, Izd-vo SO RAN.

Martello, M. (2008). Arctic Indigenous Peoples as Representations and Representatives of Climate Change, In Social Studies of Science, 38(3), 351-376.

Martynov, M.Iu. (2000). Narody khanty i mansi v usloviiakh tekhnogennoi tsivilizatsii [The peoples of the Khanty and Mansi in the conditions of technogenic civilization], In Sotsiol. Issledovaniia [Sociologist Research], 10, 64-65.

Mendeleev, N.G. (2012). Nekotorye proekty sotsial'nogo razvitiia KMNS Severa Dal'nego Vostoka i sovremennaia praktika ikh realizatsii [Some projects of social development of indigenous peoples of the North of the Far East and modern practice of their implementation], In Sotsial'nye i gumanitarnye nauki na Dal'nem Vostoke [Social and human sciences in the Far East], 1 (33), 155-160.

Mulukaev, R.S. (2010) Istoricheskii opyt zashchity prav KMNS Rossii [Historical experience of the protection of the rights of the indigenous peoples of the Russian Federation], In Istoriia gosudarstva i prava [History of State and Law], 3, 2-4.

Nancy J., Turner H. (2009) "It's so different today": Climate change and indigenous lifeways in British Columbia, Canada, In Global Environmental Change, 19 (2), 180-190. 
Naprasnikov, A.T., Ragulina, M.V., Kalep, L.L. i dr. (2005). Territorii traditsionnogo prirodopol'zovaniia Vostochnoi Sibiri: Geograficheskie aspekty obosnovaniia i analiza [Territories of traditional nature management in Eastern Siberia: Geographical aspects of justification and analysis]. Novosibirsk, Nauka, 212 p.

Popkov, Iu.V., Tiugavshev, E.A. (2005). Stsenarnyi podkhod k analizu razvitiia KMNS Severa: aktual'nost', kriterii, opyt ispol'zovaniia [Scenario approach to the analysis of the development of indigenous peoples of the North: relevance, criteria, experience of use], In Ural. ist. vestn. [Ural Historical Bulletin], 12, 140-144.

Postanovlenie Pravitel'stva Krasnoiarskogo kraia ot 30 sentiabria 2013 g. № 520-p “Ob utverzhdenii gosudarstvennoi programmy Krasnoiarskogo kraia "Sozdanie uslovii dlia povysheniia urovnia traditsionnogo obraza zhizni korennykh malochislennykh narodov Krasnoyarskogo kraia”," [Order of the Government of Krasnoyarsk Krai of September 30, 2013 "On the approval of the state program of Krasnoyarsk Krai "Creation of conditions for raising the level of the traditional way of life of the indigenous small-numbered peoples of Krasnoyarsk Krai'”'].

Proekt Strategii sotsial'no-ekonomicheskogo razvitiya Krasnoyarskogo kraya do 2030 goda [Draft Strategy for Social and Economic Development of the Krasnoyarsk Territory until 2030] (2016). Krasnoyarsk, 163. Available at: www.krskstate.ru/2030/plan

Riedlinger, D., Berkes, F. (2001). Contributions of traditional knowledge to understanding climate change in the Canadian Arctic, In Polar Record, 37 (203), 315-328.

Seredkina, N.N., Smolina, M.G., Kistova, A.V. (2017). An Epic's Impact on the Tales of the Indigenous Peoples of the North and Siberia, In Siberian Journal of Anthropology, 6 (1), 62-73.

Shapovalova, E.V. (2003). Mikroregional'nyi tip kul'tury v usloviiakh malonaselennogo Severa: dialektika sotsiokul'turnogo i khoziaystvenno-ekologicheskogo aspektov. Dis. ... kand. filos. nauk [The micro-regional type of culture in a sparsely populated North: dialectics of socio-cultural and economic-environmental aspects. PhD Thesis]. Tyumen, 135.

Sharakhmatova, V.N. (2014). Adaptatsii k izmeneniiam klimata i znachenie traditsionnykh znanii korennykh narodov Severa $\mathrm{v}$ mezhdunarodnykh proektakh i peregovornykh protsessakh [Adaptations to climate change and the importance of traditional knowledge of indigenous peoples of the North in international projects and negotiation processes], In «Na perekrestke kontinentov»: materialy XXXI Krashennik. Chtenii. M-vo kul'tury Kamch. kraya, Kamch. kraevaia nauch. b-ka im. S.P. Krasheninnikova [In «Na perekrestke kontinentov»: Proceedings of the $31^{\text {st }}$ Krashennikov Readings. Ministry of Culture of the Kamchatka region, Kamchatka Regional Research Library named after S.P. Krashennikov]. Petropavlovsk-Kamchatsky, 363-370.

Sheremata, M., Tsuji, L., Gough, W. (2016). Collaborative Uses of Geospatial Technology to Support Climate Change Adaptation in Indigenous Communities of the Circumpolar North. In Geospatial Technology - Environmental and Social Applications, 197-215.

Shmalts, M.E. (2017). Migration Trauma as a Factor in the Language Impoverishment of Indigenous Small-numbered Peoples of Siberia: the Example of the Lower Kolyma Yukaghirs, In Siberian Journal of Anthropology, 6 (1), 43-51.

Sitnikova, A.A. (2017). Review of the collective monograph «The Indigenous Small-numbered Peoples of the North and Siberia under the Conditions of Global Transformations (in the Example of the Krasnoyarsk Territory). Concept and Methodological Grounds of the Research. Ethno-cultural 
Dynamics of the Indigenous Small-numbered Peoples of the Krasnoyarsk Territory. Part I published in 2012, In Siberian Journal of Anthropology, 6 (1), 52-61.

Sondykov, B.C. (2001). KMNS Severa: problemy razvitiia i upravleniia (na primere KhantyMansiiskogo avtonomnogo okruga). Dis. ... kand. polit. nauk [Northern indigenous minorities: problems of development and management (based on the example of the Khanty-Mansiysk Autonomous Okrug). PhD Thesis]. Moscow, $181 \mathrm{p}$.

Sovremennoe polozhenie $i$ perspektivy razvitiia malochislennykh narodov Severa, Sibiri $i$ Dal'nego Vostoka [The current situation and prospects for the development of small-numbered peoples of the North, Siberia and the Far East]. (2004). Moscow, 183 p.

Spravochnaia pravovaia sistema «Konsul'tantPlius» [Legal Reference System ConsultantPlus]. Available at: www.consultant.ru/

Strategiya gosudarstvennoy kul'turnoy politiki na period do 2030 goda, utverzhdennaya Rasporyazheniem Pravitel'stva Rossiyskoy Federatsii ot 29.02.2016 № 326-r [The strategy of state cultural policy for the period up to 2030, approved by the Order of the Government of the Russian Federation of 29.02.2016 No. 326-r]. Available at: www.consultant.ru/

Strategiia razvitiia turizma v Rossiyskoi Federatsii na period do 2020 goda, utverzhdennaia Rasporiazheniem Pravitel'stva Rossiiskoi Federatsii ot 31.05.2014 № 941-r [Strategies for the development of tourism in the Russian Federation for the period until 2020, approved by the Government of the Russian Federation of May 31, 2014 No. 941-r]. Available at: http://www.consultant.ru/

Sulyandziga, P.V. (2006). Instrumenty sokhraneniia i razvitiia traditsionnogo khoziaistva KMNS Severa Rossii: regional'nyy aspect. Dis. ... kand. ekonom. nauk [Tools for the preservation and development of the traditional economy of the indigenous peoples of the North of Russia: a regional aspect. PhD Thesis]. Novosibirsk, $169 \mathrm{p}$.

Toriya, R.A. (2011). Pravovoe regulirovanie ekonomicheskogo i sotsial'nogo razvitiia KMNS Severa, Sibiri i Dal'nego Vostoka: finansovo-pravovoy aspect [Legal regulation of economic and social development of indigenous peoples of the North, Siberia and the Far East: the financial and legal aspect], In Biznes v zakone [Business in law], 2, 70-77.

Ukaz Prezidenta RF ot 24.12.2014 № 808 “Ob utverzhdenii Osnov gosudarstvennoi kul'turnoi politiki" [The Decree of the President of the Russian Federation from 24.12.2014 No. 808 "About the statement of bases of state cultural policy"]. Available at: mkrf.ru/upload/mkrf/mkdocs2016/OSNOVIPRINT.NEW.indd.pdf

Whyte, K.P., Lynn, K. (2013). Indigenous Peoples, Climate Change and the Government-toGovernment Relationship, In SSRN Electronic Journal.

Yu, Q., Epstein, H., Engstrom, R., Walker, D. (2017). Circumpolar arctic tundra biomass and productivity dynamics in response to projected climate change and herbivory, In Global Change Biology.

Yudin, V.I. (2012). Evoliutsiia gosudarstvennoi politiki Rossii v otnoshenii KMNS Severa [Evolution of the state policy of Russia in relation to Northern indigenous minorities], In Vlast' [Power], 1, 29-33.

Yudin, V.I. (2012). Gosudarstvennaia politika Rossii v otnoshenii KMNS severa: sotsial'nopoliticheskii analiz [State policy of Russia in relation to the indigenous peoples of the north: sociopolitical analysis], In Vlast' [Power], 2, 40-44. 
Zamaraeva, Y.S., Reznikova, K.V., Pimenova, N.N. (2017). The History of Anthropological Studies on the Indigenous Peoples of Siberia, In Siberian Journal of Anthropology, 6 (1), 6-21.

Zamaraeva, Y.S., Kistova, A.V., Pimenova, N.N., Seredkina, N.N. (2015). Taymyr reindeer herding as a branch of the economy and a fundamental social identification practice for indigenous peoples of the Siberian Arctic, In Mediterranean Journal of Social Sciences, 6 (3), 225-232.

Zharkova, A. (2010). Regional'naia politika organov vlasti v otnoshenii KMNS Taimyra [Regional policy of the authorities in relation to the indigenous peoples of Taimyr]. In Noril'sk, Taimyrskii filial LGU im. A.S. Pushkina, 12-20.

\title{
Нормативная правовая база муниципального, регионального, федерального и международного уровней \\ по поддержке и развитию декоративно-прикладного искусства коренных малочисленных народов
}

\author{
В.С. Лузан, Н.П. Копцева \\ Сибирский федеральный университет \\ Россия, 660041, Красноярск, пр. Свободный, 79
}

Стабильное развитие коренных малочисленных народов Севера, Сибири и Дальнего Востока Российской Федерации в условиях глобальных трансформаций зависит не только от мобилизации внутренних ресурсов самих народов, но и от реально действующих механизмов сохранения традииионных форм хозяйствования и промыслов. Особенно это становится актуальным для декоративно-прикладного искусства как одной из основных форм сохранения национальной идентичности данных народов, которая в то же время является наименее привлекательной с экономической точки зрения, в отличие, например, от традиционных форм хозяйствования (рыболовство, оленеводство, охота и т.д.). В связи с этим в статье предпринята попытка рассмотрения действующей нормативной правовой базы мунищипального, регионального, федерального и международного уровней по поддержке и развитию декоративно-прикладного искусства коренных малочисленных народов Севера, Сибири и Дальнего Востока на территории Российской Федерации.

В заключение автором обозначены общие выводы и вероятные тендениии развития нормативной правовой базы по поддержке и развитию декоративно-прикладного искусства коренных малочисленных народов в современных сочиально-экономических условиях.

Ключевые слова: коренные малочисленные народы, декоративно-прикладное искусство, культурная политика, государство, исконная среда обитания, взаимодействие.

Исследование выполнено при поддержке краевого государственного автономного учреждения «Красноярский краевой фонд поддержки научной и научно-технической деятельности» в рамках реализачии проекта: "Декоративно-прикладное искусство коренных малочисленных народов Красноярского края: современное состояние, перспективы развития.

Исследование выполнено при финансовой поддержке Российского фонда фундаментальных исследований, Правительства Красноярского края, Красноярского краевого фонда поддержки научной и научно-технической деятельности в рамках научного проекта № 17-16-24601.

Научная специальность: 24.00.00 - культурология. 